MATEC Web of Conferences 10, 03003 (2014)

DOI: $10.1051 /$ matecconf/ 20141003003

(C) Owned by the authors, published by EDP Sciences, 2014

\title{
Study on Maintenance Practices for School Buildings in Terengganu and Kedah, Malaysia
}

\author{
R. Mohammad Ropi ${ }^{1}$ and A.A. Tabassi ${ }^{2, \text { a }}$ \\ ${ }^{1,2}$ School of Housing, Building and Planning, Universiti Sains Malaysia, 11800 Penang, Malaysia
}

\begin{abstract}
Malaysia initiated talks on building maintenance in 1971 during the Second Malaysia Plan of 1971-1975. Later, the government introduced the Building and Common Property (Maintenance and Management) Act, 2007 to provide proper maintenance and management of buildings. School buildings are one of the important facilities for basic knowledge in everyday life. Accordingly, the maintenance of school buildings, which serve staff and students, needs considerable attention as effective maintenance protects capital investment, ensures the health and safety of the children, and supports educational performance. Based on a combination of literature survey and questionnaire appraisal, this study evaluates the maintenance practices in designated schools in Malaysia. Overall, the study showed that most of the school buildings do not possess their own maintenance management practices. Moreover, no preventive or planned maintenance was observed, and only emergency maintenance was applied when necessary. The study recommends the implementation of planned maintenance practices, which will be more effective than unplanned maintenance, mostly because of the reduction in repair costs.
\end{abstract}

\section{Introduction}

Maintenance is work undertaken in order to keep or restore all facilities, for example, every part of a site, building and contents, to an acceptable standard [1]. The concept of building maintenance is divided into two parts, namely building maintenance management and building maintenance technology. Building maintenance management describes how a system of maintenance works could be organized to deal with the issue of building maintenance [2]. It recognizes that aside from locating and rectifying defects, there needs to be an effective program to not only curb maintenance costs but also to maximize the benefits of the investment. This means that financial considerations and techniques play a vital role [3]. Building maintenance technology essentially deals with the study of building defects, such as deterioration of buildings [4].

The decision to carry out maintenance is influenced by the maintenance needs. The prime aim of maintenance is to preserve a building in its initial stage, and some of the main reasons for maintaining a building are to retain the value of the investment, to maintain the building in a condition where it continues to fulfil its function, and to present a good appearance [5]. Besides, effective maintenance management embraces many skills, including identifying maintenance needs and specifying the right remedies. Generally, there are four types of maintenance, namely, corrective or breakdown maintenance, scheduled maintenance, preventive maintenance and predictive maintenance [6].

\footnotetext{
${ }^{a}$ Corresponding author: akhavan@usm.my
} 
However, this thesis focuses more on two types of maintenance, which are preventive maintenance and emergency maintenance [7]. Since a comparison of each maintenance strategy depends strongly on the performance-degradation, minimum level of quality, service life and frequency of maintenance operations, these have shaped the parameters for evaluating the maintenance practices in this on-going research [8]. Even though constructing a new building helps to upgrade educational facilities and to provide a better quality of education, it is also necessary to maintain the existing building at an acceptable standard of performance so that it is capable of facilitating the transfer of knowledge and other academic activities.

\section{Methodology}

Firstly, the necessary procedures were observed. The researchers explored the problems related to maintenance practices for school buildings by searching for some related journal papers for the literature review. Secondly, the researchers came out with the objectives to be used as a guide for the research. Besides that, a hypothesis was put forward for approval in the final analysis. The case studies were selected based on the school buildings and the age of the buildings.

The majority of the selected school buildings were almost 15 years old or more. Seven case studies were selected to gather the required data for the research analysis. The school buildings that were investigated were the Sekolah Kebangsaan Keruak, Sekolah Kebangsaan LKTP Tenang, Sekolah Menengah Bukit Payong, and the Sekolah Menengah Tengku Mahmud, which are located in Terengganu. The schools in Kedah were the Sekolah Kebangsaan Sri Gudang, Sekolah Kebangsaan Seri Wang and Sekolah Kebangsaan Tun Ismail.

The study employed two methods to collect the required primary data for analysis, i.e. by using a questionnaire survey and visual inspection. Questionnaires were distributed to the teachers and those who were in charge of the maintenance in the schools. This was mostly because the study needed to know the maintenance practices that were adopted in the schools. Other than that, the visual inspections of the school buildings assisted in conducting a better analysis and provided some evidence to support the results of the study.

The visual inspections were carried out without any specific instrument and there were certain limitations as there were some places that were out of bounds to the researchers. After collecting all the data, an analysis was performed using Microsoft Excel.

\section{Observations, Results and Discussion}

These observations were made based on the overall condition of all the school buildings and not that of any one school in particular.

\subsection{Toilets}

The toilets in these schools were in a very bad condition. According to the questionnaire survey, most of the respondents were dissatisfied with the condition of the school toilets and the index interval scale was 1.81-2.6. The toilets had many defects and this will have an impact on the school building if nothing is done to rectify the problem. Besides that, it may also affect the students and teachers at the schools. The defects that were identified included toilets with mould growth, dampness, broken concrete, water leakage, and some sulphate acid. Figure 1 shows mould and fungus growing on the wall of a toilet. 


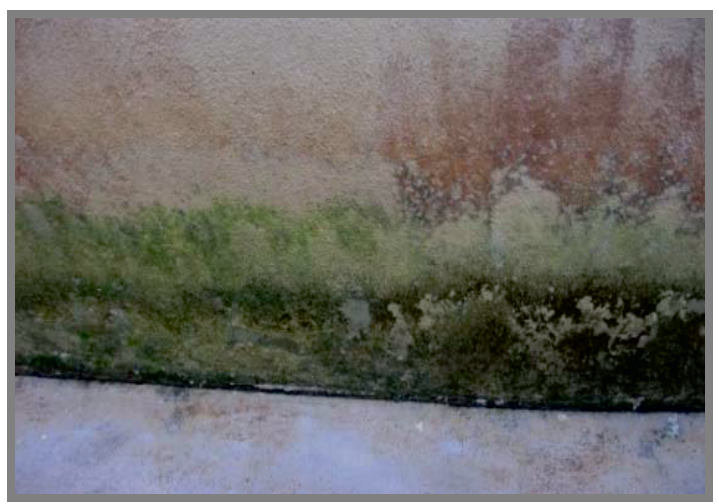

Figure 1. Mould and fungus on the wall of toilet

The defects in the toilets were very bad because the schools did not have any information on the types of defect. In addition, there was no one who was experienced in this field to do a survey for them and to make a report to the ministry. The defects will only be reported in the event that there is any damage that would endanger the students and teachers because they are still not very well-versed on the types of defects that can cause harm to the school building. Figure 2 shows the concrete spalling that occurred at the column area.

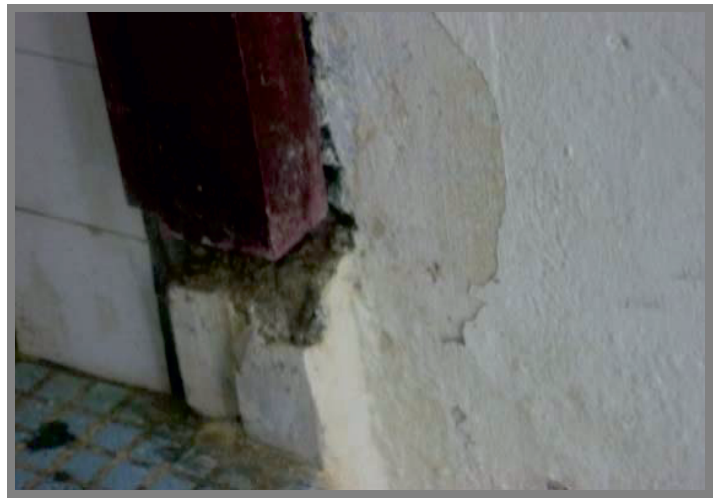

Figure 2. Concrete spalling at column area

Defects cannot only occur in the toilet, but can also occur outside the toilet. Most of the toilets at the schools had defects because they were located close to a water source. Water was the main factor behind this defect. Figure 1 shows leakage due to a broken pipe.

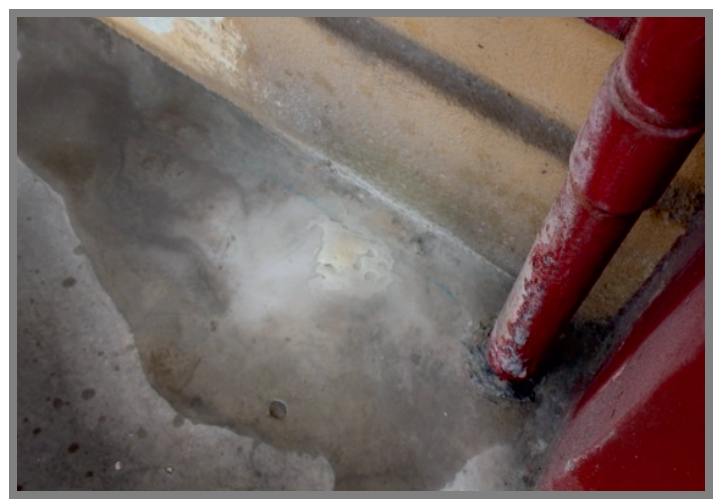

Figure 3. Leakage on floor due to broken pipe 


\subsection{Ceiling}

The ceilings were in an average condition, with an index of 2.61-3.40 on the index interval scale after analysis of the questionnaire survey. According to the visual inspections, most of the ceilings were in good condition because some problems only appeared on certain parts of the ceiling, and not on the whole ceiling. If on the whole the ceiling is riddled with problems, then it may collapse and will pose a danger to the students. Most of the ceilings had defects because of dampness. Their condition was not very dangerous. Some ceiling defects were located in the library, the classrooms, and the prayer room, and had occurred on the asbestos. Some of the asbestos were broken and this could be seen on the inside of the ceiling. Figure 4 shows the growth of mould on the ceiling.

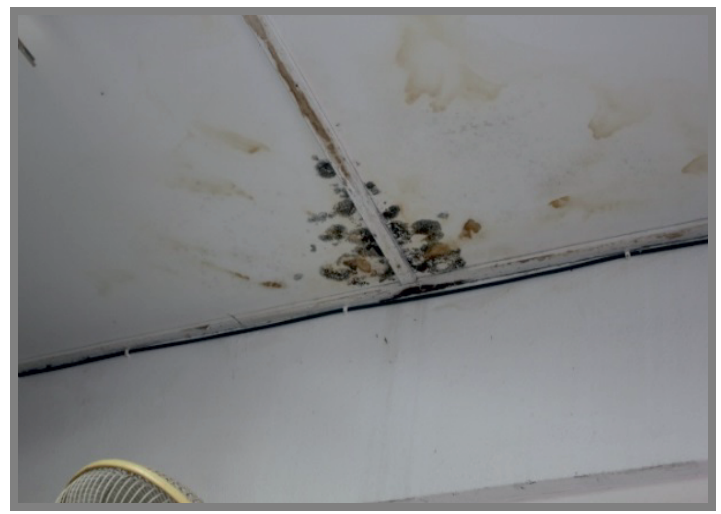

Figure 4. Mould growth on the ceiling

The defects only occurred on some of the asbestos sheets. To ensure it does not happen again, the asbestos sheets need to be replaced. Before that, the source of the dampness needs to be located and it needs to be solved first before the new asbestos sheets are put in place.

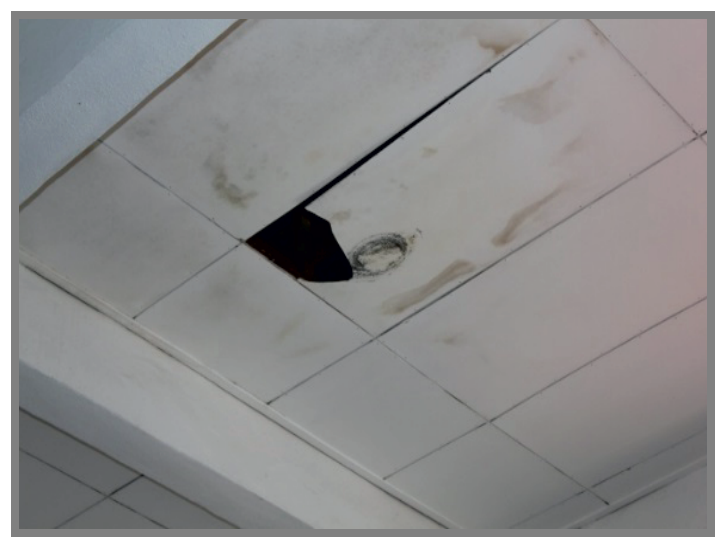

Figure 5. Dampness and broken ceiling

\subsection{Doors}

The condition of most of the doors was at an average index of 2.61-3.40. Some of the problems with the doors included broken doors (Figure 6) and termite-infested doors. The doors were broken because of student vandalism. The doors had been kicked in by naughty students until they broke. 


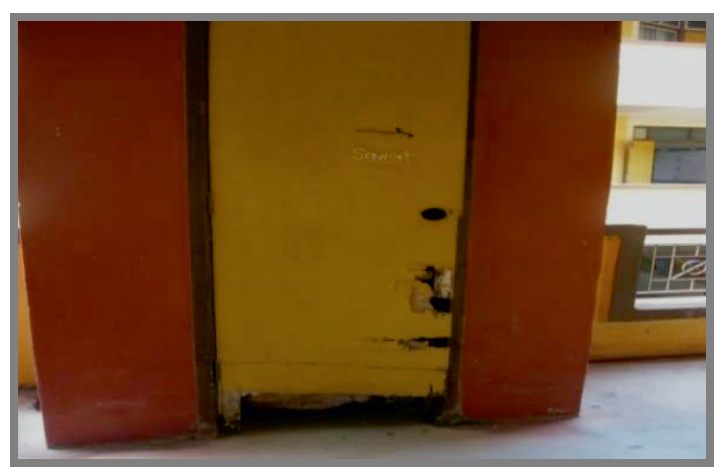

Figure 6. Broken Door near the corridor

There were also some signs of termite infestation on the doors (Figure 7). This attack by termites was because the doors were made of wood, which is food for termites. As the doors were also near to the toilets, they were constantly exposed to water, which made the wood even softer.

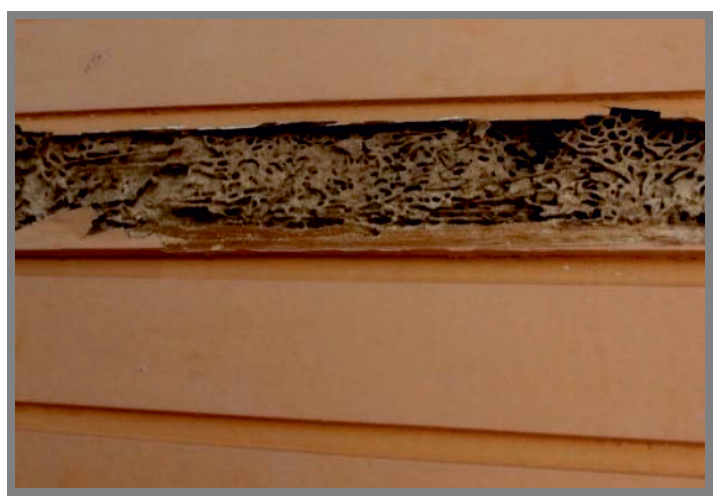

Figure 7. Termite infestation on door

\subsection{Structure}

Most of the respondents answered that of their buildings were in an average condition, with an index of 2.61-3.40 on the interval scale. Although the schools are aged 15 years or above, they are still in good condition. However, some of the schools are at a dangerous stage because they are having problems with their structure, where the buildings are experiencing some settlement (Figure 8) in the soil that might affect the three-storey buildings if precautions are not taken.

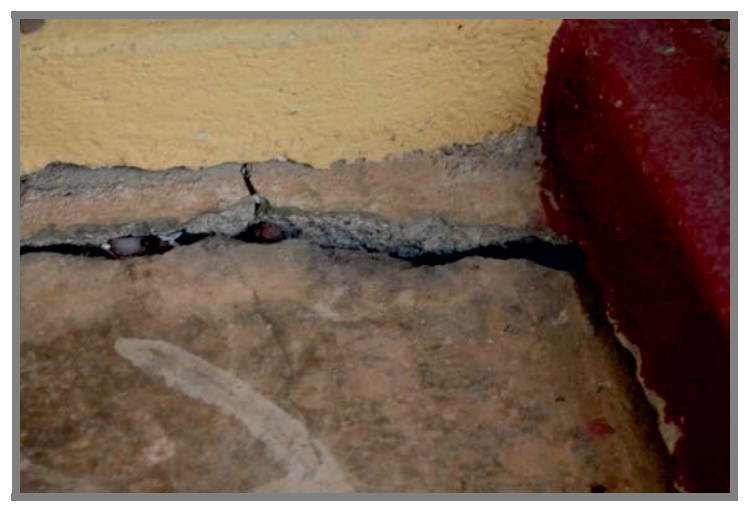

Figure 8. Cracks caused by settlement of the land 


\subsection{Maintenance Planning}

Most schools do not have their own maintenance planning but depend more on emergency planning. They do not think that planned maintenance is important for them. The schools that were surveyed do not have preventive maintenance and are only hoping that the government will carry it out. For example, they do make a report when they are faced with some problems, and they wait for the government to give out the contract to solve those problems. The school management also does not have sufficient budget for maintenance. They can only depend on the government to allocate a budget to solve those problems. There is no person in charge of the maintenance. If a problem is encountered, it will be reported to the headmaster or the principal, who will then call someone to solve it, or they will report it to the government department to settle the matter. They do not have any planned maintenance because they are not aware of the benefits of having such a plan and that it will save the building and make it last even longer. Besides, if a teacher were to complain of any problems concerning the school building, the management of the school will forward that complaint to the government department to resolve it. The schools also do not hire any professionals for maintenance as the management does not see the necessity of it because for them these are only minor problems. However, they do not know that even small problems may affect the whole building if nothing is done to prevent them for happening.

\section{Overall Analysis}

Schools in Malaysia are having some serious building defects but these are not being disclosed by anyone because the schools do not have any professional person who is in charge of maintenance management. Table 1 and Table 2 show the comparison of each element at the corresponding schools in Terengganu and Kedah. Maintenance needs to be carried out on each school building in order to prolong the life of the building.

Table 1. School in Besut Terengganu

\begin{tabular}{|c|c|c|c|c|}
\hline Element Schools & Sek Keb Keruak & Sek LKTP Tenang & $\begin{array}{c}\text { Sek Men Bukit } \\
\text { Payong }\end{array}$ & $\begin{array}{l}\text { Sek Men Tengku } \\
\text { Mahmud }\end{array}$ \\
\hline Type of maintenance & $\begin{array}{l}\text { Unplanned } \\
\text { maintenance }\end{array}$ & $\begin{array}{l}\text { Unplanned } \\
\text { maintenance }\end{array}$ & $\begin{array}{c}\text { Planned } \\
\text { maintenance }\end{array}$ & $\begin{array}{l}\text { Unplanned } \\
\text { maintenance }\end{array}$ \\
\hline Structure & Good condition & Good condition & Good condition & Good condition \\
\hline Toilet & $\begin{array}{c}\text { Not in good } \\
\text { condition }\end{array}$ & $\begin{array}{l}\text { Not in good } \\
\text { condition }\end{array}$ & $\begin{array}{l}\text { Not in good } \\
\text { condition }\end{array}$ & $\begin{array}{c}\text { Not in good } \\
\text { condition }\end{array}$ \\
\hline Wall & $\begin{array}{l}\text { Not in good } \\
\text { condition }\end{array}$ & $\begin{array}{l}\text { Not in good } \\
\text { condition }\end{array}$ & $\begin{array}{l}\text { Not in good } \\
\text { condition }\end{array}$ & Good condition \\
\hline Roof & Good condition & Good condition & Good condition & $\begin{array}{l}\text { Not in good } \\
\text { condition }\end{array}$ \\
\hline Floor & $\begin{array}{l}\text { Not in good } \\
\text { condition }\end{array}$ & $\begin{array}{l}\text { Not in good } \\
\text { condition }\end{array}$ & $\begin{array}{l}\text { Not in good } \\
\text { condition }\end{array}$ & $\begin{array}{l}\text { Not in good } \\
\text { condition }\end{array}$ \\
\hline Classroom & Good condition & Good condition & $\begin{array}{l}\text { Not in good } \\
\text { condition }\end{array}$ & Good condition \\
\hline
\end{tabular}

Table 2. School in Sungai Petani, Kedah

\begin{tabular}{|c|c|c|c|}
\hline Element & Sek Keb Sri Gudang & Sek Keb Seri Wang & $\begin{array}{c}\text { Sek Men Keb } \\
\text { Tun Ismail }\end{array}$ \\
\hline Types of Element & Unplanned maintenance & Unplanned maintenance & Unplanned maintenance \\
\hline Structure & Good condition & Not in good condition & Not in good condition \\
\hline Toilet & Not in good condition & Not in good condition & Not in good condition \\
\hline Wall & Not in good condition & Not in good condition & Good condition \\
\hline Roof & Not in good condition & Not in good condition & Not in good condition \\
\hline Floor & Good condition & Not in good condition & Not in good condition \\
\hline Classroom & Good condition & Good condition & Not in good condition \\
\hline
\end{tabular}




\section{Conclusions}

Based on a personal inspection of each school, it can be concluded that most of the schools are having various problems because of the maintenance plan that has been implemented in each school. Most of the problems in performing maintenance works in the schools are because they do not have a budget allocation that is sufficient for maintenance. Implementation should be carried out periodically, because some problems may occur continuously and are unpredictable. Most schools also have problems in their school management system. Maintenance has not been done in a long time because of the lack of efficient management and no immediate action is taken on any report of complaints or damage. The maintenance is inefficient because there is no person in charge of maintenance. The parties who are assigned to this section do not have sufficient knowledge of maintenance. The Ministry is also somewhat slow in acting on complaints of damage which does not affect the structure of the building, such as broken windows, damaged doors, etc., and to ensure the comfort of students and teachers. The teachers even contribute their own money to repair damages, to beautify and to keep the classes clean for the safety of the students themselves. School buildings which are more than 15 years old need to be examined. School buildings that are having multiple problems in certain parts need to be attended to quickly to avoid any side effects. Every school should have a person in charge with knowledge on how to manage the problems faced by the school. In addition, they should also provide maintenance management itself, without expecting immediate maintenance. If there is a person at the school who is responsible for financing proper maintenance, they won't have to depend on the Education Ministry, but will be able to resolve the issue immediately. Each school should also allocate sufficient budget to carry out any maintenance work in an emergency, without expecting the government itself to cover the expenses. A suitable maintenance management for schools is planned maintenance. Most schools do not practice regular maintenance, but carry out emergency maintenance when needed. In conclusion, each school needs to have their own maintenance department to cover the problems that they will face either today or in the future.

\section{References}

1. A.Z.A Akasah and B.M Alias, Analysis and development of the generic maintenance management process modeling for the preservation of heritage school buildings, International Journal of Integrated Engineering, 1 (2) (2009) 43-52.

2. Department of standard Malaysia, code of practice on energy efficiency and use of renewable energy for non-residential buildings (first revision), 2007

3. L. Pintellon and S.K. Pinjala, Evaluating the effectiveness of maintenance strategies, Journal of Quality in Maintenance Engineering, 12 (1) (2006) 7-20.

4. N.M. Noor, M.Y Hamid, 2011, Building maintenance budget determination: an exploration study in the Malaysia government practices. Procedia Engineering, 20 (2011) 435-444.

5. O.A. Latef, M. F. Khamidi and A. Idrus, 2010, Building Maintenance management in a Malaysia university campuses: A case study, Australasian Journal of Construction Economics and Building, 10 (1/2) (2010) 101-114

6. R.M.W. Horner, M.A.El-haram, A.k. Munnsi, Building maintenance strategy: a new management approach, Journal of quality in maintenance engineering, 3 (4) (1997) 273-280

7. S.J. Odediran, O. A. Opatunji F. O. Eghenure, Maintenance of residential buildings: user's practices in Nigeria, Journal of Emerging Trends in Economics and Management Sciences, 3 (3) (2012) 261-265

8. I.F. Colen, J.D Brito, A systematic approach for maintenance budgeting of buildings facades based on predictive and preventive strategies, Construction and Building Materials, 24 (9) (2010) 1718-1729. 